[Agr. Biol. Chem., Vol. 33, No. 6, p. 949 958, 1969]

\title{
Studies on the Bacterial Formation of a Peptide Antibiotic, Colistin
}

\author{
Part III. On the Biosynthetic Pathway of $\alpha, \gamma$-Diaminobutyric Acid \\ and Relationship between Colistin Formation and Amino \\ Acids Metabolism in Bacillus colistinus KOYAMA
}

\author{
By Mikiko Ito, Kō Aida and Teijiro Uemura \\ Institute of Applied Microbiology, University of Tokyo, Bunkyo-ku, Tokyo
}

Received November 15, 1968

\begin{abstract}
The biosynthetic pathway of $\alpha, \gamma$-diaminobutyric acid, 6 moles of which are involved in the colistin molecule as a main component, was investigated. On the basis of the isotopic results using aspartic acid-U- ${ }^{14} \mathrm{C}$ as a precursor and also the finding of transaminase activity between $\alpha$-ketoglutaric acid and $\alpha, \gamma$-diaminobutyric acid, though in reverse reaction, $\alpha, \gamma$-diaminobutyric acid was proved to be synthesized from aspartic acid via aspartylphosphate and aspartic $\beta$-semialdehyde. $\alpha, \gamma$-Diaminobutyric acid did not inhibit aspartokinase activity of this bacterium, the first enzyme involved in the process of $\alpha, \gamma$-diaminobutyric acid synthesis from aspartic acid, while the end product amino acids such as lysine, threonine and methionine showed inhibition for aspartokinase activity.

On the other hand, $\alpha, \gamma$-diaminobutyric acid might be rate-limiting factor in colistin formation, because of stimulatory effect of this diamino acid when added to the medium on colistin production. Furthermore, colistin production appeared to be related with the defect of TCA-cycle and further the resultant increase in activities of the key enzymes such as isopropylmalate synthetase, $\alpha$-acetolactate synthetase and aspartokinase involved in the biosynthetic pathways of valine, leucine and isoleucine, respectively.
\end{abstract}

$\alpha, \gamma$-Diaminobutyric acid was first found as a component of peptide antibiotic belonging to polymixin family. ${ }^{1 \sim 31}$ In the colistin molecule, 6 moles of $\alpha, \gamma$-diaminobutyric acid are involved. ${ }^{4 \prime}$ Subsequently, it has been reported by many workers that this amino acid is contained in free state in seeds of higher plants such as Lathyrus, Leguminosae and Cruciferae. ${ }^{5 \sim 71}$ Recently, S. N. Nigam and C. Ressler studied on biosynthesis of $\alpha, \gamma$-diaminobutyric acid in Lathyrus sylvestris W, and

1) P. H. Bell et al., Ann. New York Acad. Sci., 51, 867 (1949).

2) S. F. Howell, J. Biol. Chem., 186, 863 (1950).

3) W. Hausmann, ibid., 198, 405 (1952).

4) K. Suzuki, Tohoku Yakka Daigaku Kiyo, 4, 127 (1957). they confirmed that $\alpha, \gamma$-diaminobutyric acid was synthesized from both homoserine and aspartic acid. ${ }^{81}$ However, its detailed biosynthetic pathway is not yet clear.

The purpose of the present investigation was to determine biosynthetic pathway of $\alpha, \gamma$-diaminobutyric acid in Bacillus colistinus. In addition, the relationship between metabolism of amino acids, including $\alpha, \gamma$-diaminobutyric acid and colistin production was studied.

5) E. A. Bell, Nature, 193, 1078 (1962).

6) L. Fowden and M. Bryant, Biochem. J., 70, 626 (1958).

7) C. Ressler, Science, 134, 188 (1961).

8) S. N. Nigam and C. Ressler, Biochem., 5, 3426 (1966). 


\section{MATERIALS AND METHODS}

Organisms. Bacillus colistinus koyama and Escherichia coli NIHJ described in the previous paper ${ }^{9 !}$ were used throughout this study.

Radioactive compounds and chemicals. Aspartic acid$\mathrm{U}-{ }^{14} \mathrm{C}(143 \mathrm{mCi} / \mathrm{mM})$ and glutamic acid-U-14 $\mathrm{C} \quad(66$ $\mathrm{mCi} / \mathrm{mM}$ ) were purchased from Daiichi Pure Chemical Co. Ltd. Acetyl CoA and acetyl CoA-1-14C which were synthesized by $\mathrm{Mr}$. Sai were kindly supplied for the present studies. $\alpha, \gamma$-Diaminobutyric acid, pyridoxalphosphate, $\mathrm{N}^{\alpha}$-acetylaspartic acid, $\alpha$-ketoisovaleric acid, phosphoenolpyruvate, malic dehydrogenase, ATP, ADP, NAD, NADP were purchased from Sigma Chemical Comp. Other chemicals were purchased from the market.

Condition of incubation of cell suspension. Media and cultural conditions were employed as described in the previous paper. 9 / Cells grown in a synthetic medium for $20 \mathrm{hr}$ on a rotary shaker were harvested at 7,000 rpm for $20 \mathrm{~min}$, washed twice with saline and suspended in $\mathbf{M} / 10$ phosphate buffer $(\mathrm{pH} 7.2)$. The cell suspension (corresponding to $15 \mathrm{mg}$ dried cell $/ \mathrm{ml}$ ) was used in the following isotopic experiments. Reaction mixture, total volume $20 \mathrm{ml}$, contained $5 \mathrm{ml}$ of casein hydrolysate ( $5 \mathrm{mg} \mathrm{N} / \mathrm{ml}$ ), $0.5 \mathrm{ml}$ of $1 \mathrm{M}$ glucose, $10 \mathrm{ml}$ of cell suspension, $0.2 \mathrm{ml}$ of radioactive compounds $(5 \mu \mathrm{Ci} / 0.2 \mathrm{ml})$ and $4.3 \mathrm{ml}$ of $\mathrm{M} / 10$ phosphate buffer (pH 7.2). Incubation was carried out at $30^{\circ} \mathrm{C}$ for $3 \mathrm{hr}$.

Purification of radioactive colistin. After incubation, reaction mixture with radioactive asparatic acid-U-14 $\mathrm{C}$ was immediately centrifuged at $12,000 \mathrm{rpm}$ for 20 min. Supernatant was passed through Amberlite IRC $50\left(\mathrm{H}^{+}\right)$to remove unincorporated radioactive compounds. The column was completely washed with deionized water and subsequently eluted with $0.5 \mathrm{~N}$ HCl. Radioactive fraction, showing one peak in the elution pattern as illustrated in Fig. 1, had biological activity as colistin and this was further confirmed by paper chromatography. The radioactive spot of the fraction had $R f$ value identical with that of the authentic colistin on paper chromatogram using buthanol-acetic acid-pyridine-water (15:3:10:12 by vol.) as a solvent system.

Isolation and identification of radioactive $\alpha, \gamma$-diaminobutyric acid. Radioactive colistin isolated from the

9) M. Ito et al., Agr. Biol. Chem., 33, 262 (1969).

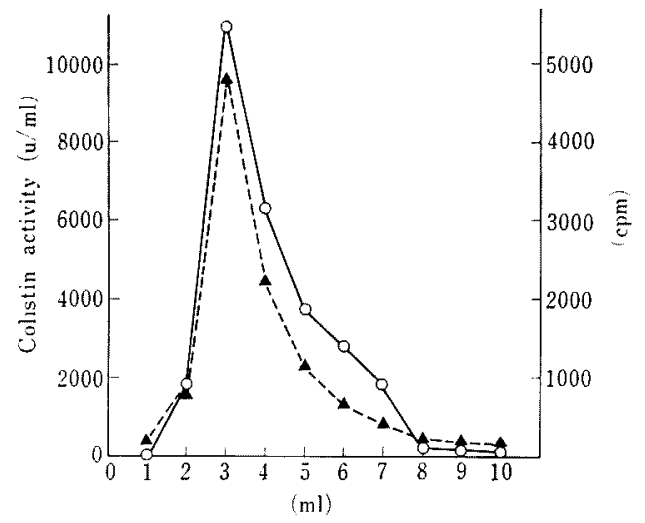

FIG. 1. Elution of Radioactive Colistin from IRC50 Column.

Supernatant of reaction mixture was applied to the column, which was treated with $15 \mathrm{ml}$ of water, and successively eluted with $0.5 \mathrm{~N} \mathrm{HCl}$. The flow rate was approximately $5 \mathrm{ml}$ per hour. Each fraction was $1 \mathrm{ml}$.

-O Colistin activity

above spot was hydrolyzed with $6 \mathrm{~N} \mathrm{HCl}$ in a sealed tube for $8 \mathrm{hr}$ by autoclaving. Hydrolyzate was evaporated to dryness. Evaporation was repeated with addition of a small amount of water. The preparation was again dissolved in a small amount of water and was used for paper chromatography and radioautography. Isolation was carried out by paper chromatography using solvent system of buthanolacetic acid-water ( $3: 1: 1$ by vol.) and identification by radioautography on Fuji medical X-ray film.

Enzyme assay. After washed cells were disintegrated with sonic oscillator at $10 \mathrm{kC}$ for $15 \mathrm{~min}$, disrupted cells were centrifuged at $12,000 \mathrm{rpm}$ for $30 \mathrm{~min}$. The supernatant was dialyzed and used as crude enzyme preparation. In the case of assay of aspartokinase and $\mathrm{N}^{\alpha}$-acetylaspartokinase, the fractions precipitated with 0.6 or 0.9 saturated ammonium sulfate were used, respectively. Assay of aspartokinase and $\mathrm{N}^{\alpha_{-}}$ acetylaspartokinase was carried out by Black and Wright's method.101 Transaminase between $\alpha$-ketoglutaric acid and $\alpha, \gamma$-diaminobutyric acid was investigated by Souda's modified method.11) The assay of transaminase activity between $\alpha$-ketoglutaric acid

10) Black and Wright, "Methods in Enzymology," V, 821P (1962).

11) K. Souda, Agr. Biol. Chem., 25, 811 (1961). 
and lysine was done by the similar method. Citrate condensing enzyme was measured by method of S. Ochoa, ${ }^{12)}$ isocitrate dehydrogenase by the increase of TPNH at $340 \mathrm{~m} \mu,{ }^{13)}$ phosphoenolpyruvate carboxylase and pyruvate carboxylase by method of $\mathrm{M}$. Runz Amil,14) and $\alpha$-acetolactate synthetase by method of W. Westerfeld. $\left.{ }^{15}\right)$ Assay of $\alpha$-isopropylmalate synthetase was done according to Sai's(6) method of citramalate synthetase, using acetyl CoA and $\alpha$-ketoisovalerate, instead of pyruvate, as substrates.

Determination of protein. The method of Lowry et al. using the Folin-Ciocalteu reagent ${ }^{17}$ ) was employed for this purpose.

Determination of radioactivity. Radioactivity was counted with a Aloka Model PC-10D windowless gasflow counter.

\section{RESULTS}

1) Biosynthetic pathway of $\alpha, \gamma$-diaminobutyric acid Aspartic acid-U- ${ }^{14} \mathrm{C}$ and glutamic acid-U${ }^{14} \mathrm{C}$ were employed as a possible precursor in

TABLE 1. INCORPORATION OF LABELED AMINO ACIDS INTO $\alpha, \gamma$-DIAMINOBUTYRIC ACID of Colistin

\begin{tabular}{lcrc}
\multicolumn{1}{c}{ Labeled } & $\begin{array}{c}\text { Colistin } \\
\text { activity } \\
\text { (unit) }\end{array}$ & $\begin{array}{r}\text { Total } \\
\text { count } \\
\text { (cpm) }\end{array}$ & $\begin{array}{c}\text { Specific } \\
\text { activity } \\
\text { (cpm/u) }\end{array}$ \\
$\begin{array}{l}\text { L-Glutamic } \\
\text { acid-U-14C }\end{array}$ & 11,000 & 815 & 0.074 \\
$\begin{array}{l}\text { L-Aspartic } \\
\text { acid-U-14C }\end{array}$ & 11,500 & 114,000 & 9.87 \\
$\begin{array}{l}\text { L-Aspartic acid- } \\
\text { U-14 } \mathrm{C}+\alpha, \gamma \text {-diamino- } \\
\text { butyric acid-12G }\end{array}$ & 13,000 & 6,980 & 0.54 \\
\end{tabular}

Reaction mixture; cell suspension $10 \mathrm{ml}$ (corresponding to $150 \mathrm{mg}$ dried cell), $1 \mathrm{M}$ glucose $0.5 \mathrm{ml}$, amino acids mixture $5 \mathrm{ml}, \mathbf{M} / 10$ phosphate buffer ( $\mathrm{pH} 7.2$ ) Asp-U-14 C $5 \mu \mathrm{Ci}$ or Glu-U-14 $\mathrm{C} 5.7 \mu \mathrm{Ci}$, Total volume $20 \mathrm{ml}$. Incubation: $30^{\circ} \mathrm{C}, 3 \mathrm{hr}$.

12) S. Ochoa, "Methods in Enzymology,'" I, 685p (1955).

13) N. O. Kaplan, "Methods in Enzymology," III, 892 (1957).

14) M. Runz Amil, J. Biol. Chem., 240, 3485 (1965).

15) W. W. Westerfeld, J. Biol. Chem., 161, 495 (1945).

16) T. Sai et al., Agr. Biol. Chem., 32, 1398 (1968).

17) Lowry et al., J. Biol. Chem., 193, 265 (1951). the biosynthesis of $\alpha, \gamma$-diaminobutyric acid and incorporation of these labeled amino acids into colistin was examined with cell suspension. As shown in Table $I$, only very small amount of glutamic acid-U- ${ }^{14} \mathrm{C}$ was incorporated into colistin, while aspartic acid- $U-{ }^{14} \mathrm{C}$ was highly incorporated into colistin. Furthermore, addition of $\alpha, \gamma$-diaminobutyric acid- ${ }^{12} \mathrm{C}$ to cell suspension in the presence of aspartic acid-U- ${ }^{14} \mathrm{C}$ strongly inhibited the incorporation of aspartic acid-U- ${ }^{14} \mathrm{G}$ into colistin, and specific activity of colistin formed in this reaction system was lower than that when aspartic acid-U $-{ }^{14} \mathrm{C}$ alone was supplied. The specific activity of colistin was expressed as radioactivity (cpm) to biological activity (u) shown by colistin. Therefore, aspartic acid but not glutamic acid may be the precursor of $\alpha, \gamma-$ diaminobutyric acid involved in colistin molecule.

To confirm the above incorporation test, labeled colistin was isolated from the supernatant of the incubated mixture with cell suspension as described in the Methods, and, adding $10 \mathrm{mg}$ of the authentic colistin as

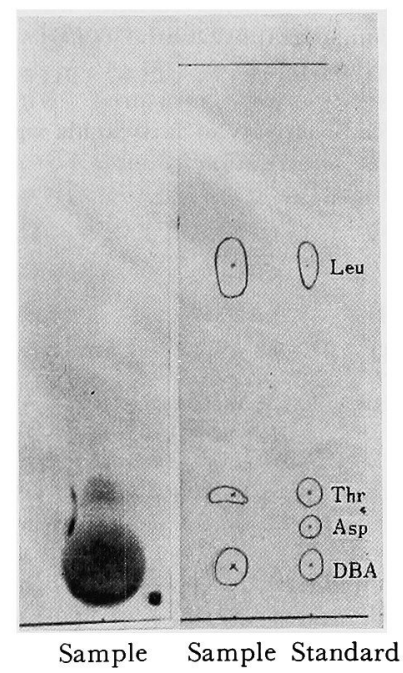

FIG. 2. Radioautogram of Hydrolysate of Labeled Colistin Formed from Aspartic Acid-U-14C (left) and Ninhydrin Spots (right). 
carrier, it was hydrolyzed with $5 \mathrm{~N} \mathrm{HCl}$. After hydrolyzation, the labeled preparation was subjected to a chromatography, in which solvent system used was buthanol-acetic acid water $(3: 1: 1$ by vol.). The paper developed was completely dried and radioautography was carried out. Fuji medical X-ray film was exposured with the paper developed for 10 days, after which the paper separated from $\mathrm{X}$-ray film was colored with ninhydrin for the detection of amino acids. Figure 2 shows paperchromatogram and radioautogram of hydrolyzate of labeled colistin formed in the presence of aspartic acid-U- ${ }^{14} \mathrm{C}$ with cell suspension. Radioactive spots were found in the sites corresponding to authentic $\alpha, \gamma$-diamino-

\begin{tabular}{|c|c|c|}
\hline \multicolumn{3}{|c|}{$\begin{array}{l}\text { TABLE II. DISTRIBUTION OF RAdIOAC } \\
\text { THE CASE OF INCORPORATION OF L-A } \\
\text { ACID-U-14C INTO COLISTIN }\end{array}$} \\
\hline $\begin{array}{l}\text { Component of } \\
\text { colistin }\end{array}$ & $\begin{array}{l}\text { Total count } \\
(\mathrm{cpm})\end{array}$ & $\begin{array}{c}\text { Distribution } \\
(\%)\end{array}$ \\
\hline Leucine & 0 & 0 \\
\hline Threonine & 210 & 17 \\
\hline$\alpha, \gamma$-Diaminobutyric acid & 1160 & 83 \\
\hline $\begin{array}{l}\text { 6-Methyloctanoic acid } \\
\text { and isooctanoic acid }\end{array}$ & 0 & 0 \\
\hline
\end{tabular}

Hydrolysate of labeled colistin was carried out paper chromatography with $\mathrm{BuOH}: \mathrm{AcH}: \mathrm{H}_{2} \mathrm{O}$ (3:1:1 by vol.).

Radioactivity was measured with gas-flow counter. Radioactivity of fatty acids was measured with liquids scintillation counter. butyric acid and threonine, although radioactive spot of threonine was far weaker than that of $\alpha, \gamma$-diaminobutyric acid.

Furthermore, to clarify the intensity distribution in radioactivity of the components of labeled colistin, each spot on the paper chromatogram colored with ninhydrin and bromcresolgreen was cut off, eluted with water and a aliquot of eluates was counted with gas-flow counter. The result of intensity distribution of radioactive compounds obtained is shown in Table II. Most of radioactivity of the components of colistin molecule was found in $\alpha, \gamma$-diaminobutyric acid, which occupied $83 \%$, while radioactivity in threonine was distributed to an extent of $17 \%$. Thus, it was confirmed that $\alpha, \gamma$-diaminobutyric acid was derived from aspartic acid in the present bacterium in the same manner as was found in Lathyrus sylverstis W.

From these results, two biosynthetic pathways as illustrated in Fig. 3 were assumed to be possible. One of them is the conversion of aspartate to $\alpha, \gamma$-diaminobutyric acid via $\beta$-aspartylphosphate and aspartate- $\beta$-semialdehyde and another is that $\alpha, \gamma$-diaminobutyric acid is synthesized from aspartic acid via the corresponding $\mathrm{N}$-acetylated intermediates, such as $\mathrm{N}$-acetylaspartate, $\mathrm{N}$-acetyl- $\gamma$-aspartylphosphate, $\mathrm{N}$-acetylspartic- $\gamma$-semialdehyde and $\mathrm{N}$ acetyl- $\gamma$-aminobutyric acid. The formation
I)

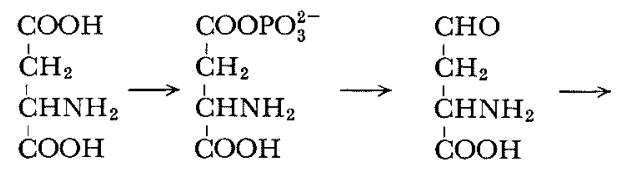
$\mathrm{CH}_{2} \mathrm{NH}_{2}$
$\stackrel{1}{\mathrm{C}} \mathrm{H}_{2}$
$\stackrel{\mathrm{C}}{\mathrm{CHNH}} \mathrm{N}_{2}$
$\mathrm{COOH}$
$\begin{array}{llll}\text { Aspartic } & \beta \text {-Aspartyl } & \text { Aspartic } & \alpha, \gamma \text {-Diaminobutyric } \\ \text { acid } & \text { phosphate } & \beta \text {-semialdehyde } & \text { acid }\end{array}$
II) $\mathrm{COOH}$

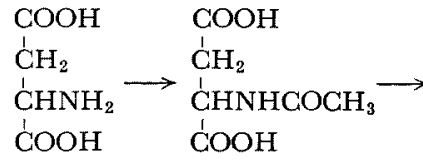
Aspartic
$\mathrm{N}$-Acetyl
aspartic acid
$\mathrm{COOPO}_{3}^{2-}$
$\mathrm{COOH}$
N-Acetyl
$\beta$-aspartyl
phosphate
$\mathrm{CHO}$
$\mathrm{CHO} \quad \mathrm{CH}_{2} \mathrm{NH}_{2}$
$\stackrel{\mathrm{C}}{\mathrm{C}} \mathrm{H}_{2}$
$\mathrm{CH}_{2}$
$\mathrm{CHNHCOCH}$
3
$\mathrm{CHNHCOCH}_{3}$ $\mathrm{COOH}$
N-Acetyl
aspartate

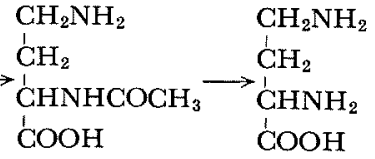
$\alpha, \gamma$-Diamino- butyric acid

FIG. 3. Probable Biosynthetic Pathways of $\alpha, \gamma$-Diaminobutyric Acid. 
of $\alpha, \gamma$-diaminobutyric acid from $\mathrm{N}$-acetyl- $\gamma-$ aminobutyric acid may be catalyzed by a hydrolytic enzyme like acetylorinithinase of E. coli. ${ }^{181}$

Then, enzyme activities related to the first step, i.e. those of aspartokinase and $\mathrm{N}^{\alpha}$-acetylaspartokinase activities were investigated, using the enzyme preparation precipitated with 0.6 saturated $\left(\mathrm{NH}_{4}\right)_{2} \mathrm{SO}_{4}$. As shown in Table III, aspartokinase activity was 0.374 ,

TABLE III. ASPARTOKINASE AND $\mathrm{N}^{\alpha}$-ACETYLASPARTOKINASE ACTIVITIES

$\begin{array}{lc}\quad \text { Substrate } & -\log T(\text { at } 540 \mathrm{~m} \mu) \\ \text { L-Aspartic acid } & 0.374 \\ \mathrm{~N}^{\alpha} \text {-Acetylaspartic acid } & 0.012 \\ \mathrm{~N}^{\alpha} \text {-Acetylaspartic acid* } & 0.002\end{array}$

The assay mixture contained ATP $10 \mu$ moles, $\mathrm{NH}_{2} \mathrm{OH}-\mathrm{HCl} 800 \mu$ moles, $\mathrm{MgCl}_{2} 10 \mu$ moles, L-Asp. $100 \mu$ moles, crude enzyme preparation (fraction precipitated with 0.6 saturated $\left(\mathrm{NH}_{4}\right)_{2} \mathrm{SO}_{4}, 7.2 \mathrm{mg}$ protein per $\mathrm{ml}$ ) Incubation; at $26^{\circ} \mathrm{C}$, for $30 \mathrm{~min}$.

After addition of $\mathrm{FeCl}_{3}$ reagent, the optical density of the aspartohydroxamate-ion complex was measured at $540 \mathrm{~m} \mu$.

* Fraction precipitated with 0.9 saturated $\left(\mathrm{NH}_{4}\right)_{2} \mathrm{SO}_{4}$ was used as enzyme solution, and the amount of enzyme protein was the same as preliminary experiment.

while $\mathrm{N}^{\alpha}$-acetylaspartokinase activity was very weak and only 0.012 with the reaction mixtures containing $7.2 \mathrm{mg}$ of crude enzyme protein in each tube. Furthermore, when $\mathrm{N}^{\alpha}$ acetylaspartokinase activity was assayed with the preparation obtained with 0.9 saturated ammonium sulfate, the activity was also as weak as the above enzyme preparation. Thus, the enzyme preparations so far tested were assumed to exhibit aspartokinase alone and accordingly the alternative scheme II was ruled out from the assumption.

Biosynthesis of $\alpha, \gamma$-diaminobutyric acid from aspartic acid appears to involve a conversion of $\alpha, \gamma$-diaminobutyric acid to aspartic $\beta$-semialdehyde which is the reverse reaction of the

18) Henry J. Vogel, J. Biol. Chem., 218, 97 (1956). final step in this biosynthesis. As to the transamination of $\beta$-semialdehyde compounds, Fincham ${ }^{191}$ once observed that mycerial extracts of Neurospora crassa catalyze transamination of ornithine to $\alpha$-ketoglutaric acid to form glutamic semialdehyde and glutamic acid, respectively. Then, transamination between $\alpha, \gamma$-diaminobutyric acid and several kinds of $\alpha$-keto acids was preliminarily tested as using the crude enzyme extracts, where transamination of $\alpha, \gamma$-diaminobutyric acid was predicted to result in the formation of aspartic semialdehyde. Of $\alpha$-keto acids tested, only $\alpha$ ketoglutaric acid gave positive result in the formation of glutamic acid and thus this $\alpha$-keto acid seemed to be an active substrate for the transamination, whereas pyruvic acid or oxaloacetic acid, reacting with $\alpha, \gamma$-diaminobutyric acid, was not converted into the corresponding amino acids such as alanine or aspartic acid. Therefore, $\alpha, \gamma$-diaminobutyric acid and $\alpha$-ketoglutaric acid were used as substrates in the reaction system of transamination, in which glutamic acid formed was quantitatively assayed according to Giri's method. ${ }^{201}$

Table IV shows the formation of glutamic acid resulting from the transamination of $\alpha, \gamma-$ diaminobutyric acid to $\alpha$-ketoglutaric acid.

TABle IV. TRansamination BetweEn L- $\alpha, \gamma-$ DIAMINOBUTYRIC ACID AND $\alpha$-KetoGLUTARIC ACID

$\begin{array}{lc}\text { Reaction system } & \text { Activity* } \\ \text { Complete system } & 1.59 \\ \text { Minus L- } \alpha, \gamma \text {-diaminobutyric acid } & 0.080 \\ \text { Minus } \alpha \text {-ketoglutaric acid } & 0.073 \\ \text { Minus enzyme } & 0.073\end{array}$

Incubation mixture contained $\alpha, \gamma$-diaminobutyric acid $20 \mu$ moles, $\alpha$-ketoglutaric acid $20 \mu$ moles, pyridoxal phosphate $1 \mu$ mole, crude enzyme $(3.5$ mg protein), phosphate buffer $100 \mu$ moles (pH 8.0). Incubation carried out at $37^{\circ} \mathrm{C}$, for $60 \mathrm{~min}$.

* Glutamate formed ( $\mu$ moles)/mg of protein $/ 60$ min.

19) H. R. S. Fincham, Biochem. J., 53, 313 (1953).

20) E. V. Giri, Nature, 170, 1025 (1952). 
Glutamic acid there formed was well determined only in the complete system but not, if any, in reaction systems lacking either one of amino donor, amino acceptor or crude enzyme solution. Thus, the transamination between $\alpha, \gamma$-diaminobutyric acid and $\alpha$-ketoglutaric acid, though reversedly to the final step in the formation process of $\alpha, \gamma$-diaminobutyric acid, was well performed with the crude enzyme extracts of this organism. In this case, in order to obtain active enzyme extracts a special caution was required at the disruption of cells with sonic oscillator, where $1 \mu$ mole of pyridoxal-5'-phosphate and $1 \mu$ mole of glutathione were added to $1.0 \mathrm{ml}$ of the cell suspension. If cells were disrupted in the absence of pyridoxal-5'-phosphate, this transamination activity was not at all detectable in the resultant cell extracts, so that pyridoxal$5^{\prime}$-phosphate seemed to act as a protecting agent for the enzyme activity.

Furthermore, identification of reaction products were carried out with paperchromatography using butanol-acetic acid-water $(4: 1: 2$

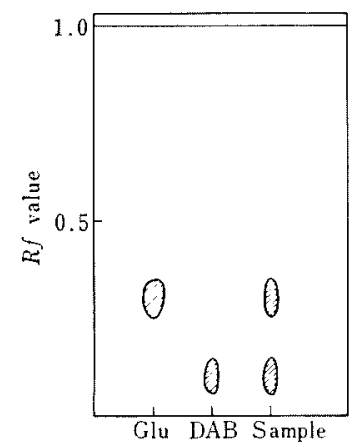

FIG. 4. Paper Chromatogram for Identification of Reaction Product.

Solvent system: butanol : acetic acid : water (4: $1: 2$ by vol.).

Left: a spray reagent used $0.5 \%$ ninhydrin dissolved in $95 \%$ acetone.

Right: ammoniacal silver nitrate was sprayed.

Abbreviation: Glu, glutamic acid; DAB, $\alpha, \gamma-$ diaminobutyric acid; $\alpha$-Kg, $\alpha$-ketoglutaric acid; Asp- $\beta$-semialdehyde, Aspartic $\beta$-semialdehyde. by volume) as a solvent system. As shown in Fig. 4, a spot corresponding to glutamic acid as sprayed with $0.5 \%$ ninhydrin solution was identified by comparing it with that of the authentic compound. On the other hand, when the developed paper was sprayed with ammoniacal silver nitrate solution, a spot of the other reaction product, aspartic $\beta$-semialdehyde, was though not distinctly separable from that of $\alpha$-ketoglutaric acid because of tailing, well-discernible when compared with the spot of the authentic compound.

From the results, it is concluded that $\alpha, \gamma$ diaminobutyric acid is synthesized from aspartic acid via aspartylphosphate and aspartic $\beta$-semialdehyde which in turn is successively transaminated with glutamic acid as illustrated in Fig. 3-I, and that no N-acetylation of aspartic acid participates in the reaction series of this biosynthesis.

2) Amino acid metabolism and colistin formation

As reported previously, ${ }^{9 \prime}$ valine, leucine and isoleucine are abundantly but glutamic acid is poorly pooled within the colistin-producing cell, whereas the reverse is the case within the colistin-not-producing cell. The former cell is obtained from the culture in the synthetic medium containing starch as carbon source while the latter from the culture in the glucose-bouillon medium. The above fact suggests that in colistin producing cells, the metabolism of amino acids is so altered as to produce much more of the amino acids of pyruvate series such as valine and leucine as well as of aspartate series such as isoleucine, including $\alpha, \gamma$-diaminobutyric acid, a main amino acid component of colistin and is derived from aspartic acid as already mentioned, thus providing components of colistin. Then, activities of key enzymes and related ones in the biosyntheses of these amino acids were investigated, by using enzyme preparations obtained from both cells above mentioned.

As summarized in Table $\mathrm{V}$, the enzyme 
TABLE V. COMPARISON OF ENZYME ACTIVITIES between Colistin Producing Cells* AND COLISTIN NOT-PRODUCING CELLS**

\begin{tabular}{|c|c|c|c|}
\hline $\begin{array}{r}\text { Col } \\
\text { prod } \\
\text { ce }\end{array}$ & $\begin{array}{l}\text { istin } \\
\text { lucing } \\
\text { ells }\end{array}$ & $\begin{array}{l}\text { Colistin not- } \\
\text { producing } \\
\text { cells }\end{array}$ & $\begin{array}{l}\text { Units } \\
\text { of } \\
\text { enzymes }\end{array}$ \\
\hline $\begin{array}{l}\text { Citrate condensing } \\
\text { enzyme }\end{array}$ & 0 & 9.25 & $\begin{array}{l}\mu \mathrm{moles} / \mathrm{min} / \\
\mathrm{mg} \text { protein }\end{array}$ \\
\hline $\begin{array}{l}\text { Isocitrate } \\
\text { dehydrogenase }\end{array}$ & 0 & 13.9 & "I \\
\hline $\begin{array}{l}\text { Phosphoenolpyruvate } \\
\text { carboxylase }\end{array}$ & 16.6 & 1064 & $\begin{array}{l}\mathrm{cpm} / \mathrm{mg} \\
\text { protein } / 15 \mathrm{~min}\end{array}$ \\
\hline $\begin{array}{l}\text { Pyruvate } \\
\text { carboxylase }\end{array}$ & 0 & 0 & " \\
\hline $\begin{array}{l}\alpha \text {-Acetolactate } \\
\text { synthetase (pH 6.0) }\end{array}$ & 38.8 & 22.1 & $\begin{array}{l}u / \mathrm{mg} \text { protein/ } \\
60 \mathrm{~min}\end{array}$ \\
\hline " $\quad(\mathrm{pH} 8.0)$ & 15.8 & 7.5 & $" \prime$ \\
\hline $\begin{array}{l}\alpha \text {-Isopropylmalate } \\
\text { synthetase }\end{array}$ & 4.9 & 1.4 & $\begin{array}{l}\mathrm{m} \mu \mathrm{moles} / \mathrm{mg} \\
\text { protein } / \mathrm{hr}\end{array}$ \\
\hline Aspartokinase & 0.492 & 0.133 & $\begin{array}{l}-\log T \text { at } 540 \\
\mathrm{~m} \mu / 7.2 \mathrm{mg} \\
\text { protein/hr }\end{array}$ \\
\hline
\end{tabular}

* Cells grown in synthetic medium, colistin formed $5000 \sim 7000 \mathrm{u} / \mathrm{ml}$.

** Cells grown in glucose bouillon medium, colistin formed $0 \sim 1000 \mathrm{u} / \mathrm{ml}$.

preparation obtained by fractionation with 0.6 saturated ammonium sulfate from the crude extract of the colistin-producing cell exhibited considerable activities of $\alpha$-acetolactate synthetase ( $\mathrm{pH} 6.0$ and $\mathrm{pH} 8.0$ ), $\alpha$-isopropylmalate synthetase and aspartokinase, respectively. Whilst, in this cell, activities of some TCA cycle enzymes such as citrate condensing enzyme and isocitrate dehydrogenase were entirely, if any, eliminated and a little activity of phosphoenolpyruvate carboxylase was detected. In contrast, the reverse was the case in these enzymatic activities of the colistin-not-producing cell and considerable activity was observable in the enzymes involved in TCA cycle, especially a remarkable one in phosphoenolpyruvate carboxylase, while the enzymes concerned with biosyntheses of valine, leucine and isoleucine, such as $\alpha$-acetolactate synthetase, $\alpha$-isopropylmalate synthetase and aspartokinase, showed lower activity compared with those of the colistinproducing cells. Both of the cells, in addi- tion, were defective in pyruvate carboxylase. Thus, the colistin-producing cell is well characterized by the defect of the key enzymes performing in TGA cycle but enrichment of the key enzyme involved in the biosyntheses of valine, leucine and isoleucine. This may give rise to enrichments of these amino acids pooled within the cell, resulting in the formation of colistin.

In view of the distribution of amino acids composed of colistin molecule, it is assumed that an inclination to the formation of $\alpha, \gamma-$ diaminobutyric acid, exceeding that of other amino acids, especially of threonine, occurs in the colistin-producing cell. Since this diamino acid is derived from aspartic acid which in turn may result from oxaloacetic acid possibly formed by phosphoenolpyruvate carboxylase, though of low activity, aspartokinase is of importance not only for biosyntheses of lysine, threonine and isoleucine, as is well

Table VI. EFfect of Various End Products ON ASPARTOKINASE ACTIVITY

\begin{tabular}{lcc}
\multicolumn{1}{c}{ Additions } & $\begin{array}{c}-\log T \\
\text { (at } 540 \mathrm{~m} \mu)\end{array}$ & $\begin{array}{c}\text { Inhibition } \\
(\%)\end{array}$ \\
None & 0.495 & 0 \\
L-Lysine $50 \mathrm{mM}$ & 0.125 & 74.7 \\
L-Lysine $5 \mathrm{mM}$ & 0.445 & 10.1 \\
L-Threonine $50 \mathrm{mM}$ & 0.285 & 42.4 \\
$\quad$ " $5 \mathrm{mM}$ & 0.445 & 10.1 \\
L-Methionine $50 \mathrm{mM}$ & 0.382 & 22.8 \\
$\quad$ " $25 \mathrm{mM}$ & 0.482 & 2.6 \\
L- $\alpha, \gamma$-Diaminobutyric & 0.550 & 0 \\
acid 50 mM (DAB) & & \\
L- $\alpha$-Aminobutyric & 0.550 & 0 \\
acid 50 mM & & \\
L-Lysine+L-DAB & 0.140 & 71.7 \\
50 mM each & & \\
L-Threonine + L-DAB & 0.255 & 48.4 \\
50 mM each & &
\end{tabular}

The assay mixture contained ATP $10 \mu$ moles, $\mathrm{NH}_{2} \mathrm{OH} \cdot \mathrm{HCl} 800 \mu$ moles, $\mathrm{MgCl}_{2} 10 \mu$ moles, L-Asp. $100 \mu$ moles, each end product inhibitor and enzyme solution ( $8.6 \mathrm{mg}$ of protein). Total volume was $1.0 \mathrm{ml}$ and incubation was carried out at $26^{\circ} \mathrm{C}$, for $30 \mathrm{~min}$. After addition of $\mathrm{FeCl}_{3}$ reagent, the optical density of the aspartohydroxamate-ion complex was measured at $540 \mathrm{~m} \mu$. 
known, but also for the formation of $\alpha, \gamma$ diaminobutyric acid. It is also known that activity of aspartokinase is variously governed by the endproduct amino acids and $\alpha$-aminobutyric acid, but effect of $\alpha, \gamma$-diaminobutyric acid on it is as yet unknown. Then, effects of this diamino acid as well as other monoamino acids mentioned above were investigated, using crude enzyme extracts obtained from the colistin-producing cell. The results obtained are shown in Table VI. An inhibition was observed, though to various extents, by addition of L-lysine, L-threonine and L-methionine, respectively, to the reaction mixture, whereas $\alpha$-aminobutyric acid and $\alpha, \gamma$-diaminobutyric acid were of no effect. Thus, inhibition rate showed $74.7 \%$ by L-

TABLE VII. CONCERTED FEEDBACK INHIBITION oF ASPARTOKINASE ACTIVITY

\begin{tabular}{|c|c|c|}
\hline Additions & $\begin{array}{l}-\log T \\
\text { at } 540 \mathrm{~m} \mu)\end{array}$ & $\begin{array}{c}\text { Inhibition } \\
(\%)\end{array}$ \\
\hline None & 570 & 0 \\
\hline L-Lysine $5 \mathrm{~mm}$ & 570 & 0 \\
\hline L-Threonine $5 \mathrm{mM}$ & 570 & 0 \\
\hline $\begin{array}{l}\text { L- } \alpha, \gamma \text {-Diaminobutyric } \\
\text { acid (DAB) } 5 \mathrm{mM}\end{array}$ & 570 & 0 \\
\hline L-Lysine + L-threonine $5 \mathrm{~mm}$ each & 35 & 93.8 \\
\hline $\begin{array}{l}\text { L-Lysine+L-threonine } \\
+ \text { DAB } 5 \mathrm{mM} \text { each }\end{array}$ & 45 & 92.1 \\
\hline $\begin{array}{l}\text { L-Lysine }+ \text { L-threonine } \\
2.5 \mathrm{mM} \text { each }\end{array}$ & 185 & 67.5 \\
\hline $\begin{array}{l}\text { L-Lysine } 2.5 \mathrm{mM} \\
\text { +L-threonine } 2.0 \mathrm{mM}\end{array}$ & 195 & 65.7 \\
\hline $\begin{array}{l}\text { L-Lysine } 2.5 \mathrm{mM} \\
\text { +L-threonine } 1.5 \mathrm{mM}\end{array}$ & 320 & 43.8 \\
\hline $\begin{array}{l}\text { L-Lysine } 2.5 \mathrm{~mm} \\
\text { +L-threonine } 1.0 \mathrm{mM}\end{array}$ & 395 & 30.7 \\
\hline $\begin{array}{l}\text { L-Lysine } 2.5 \mathrm{mM} \\
\text { +L-threonine } 0.5 \mathrm{mM}\end{array}$ & 500 & 12.2 \\
\hline $\begin{array}{l}\text { L-Lysine } 2.0 \mathrm{mM} \\
+ \text { L-threonine } 2.5 \mathrm{mM}\end{array}$ & 165 & 71.0 \\
\hline $\begin{array}{l}\text { L-Lysine } 1.5 \mathrm{~mm} \\
\text { +L-threonine } 2.5 \mathrm{mM}\end{array}$ & 255 & 55.2 \\
\hline $\begin{array}{l}\text { L-Lysine } 1.0 \mathrm{~mm} \\
+\mathrm{L} \text {-threonine } 2.5 \mathrm{~mm}\end{array}$ & 380 & 33.3 \\
\hline $\begin{array}{l}\text { L-Lysine } 0.5 \mathrm{mM} \\
\text { + L-threonine } 2.5 \mathrm{mM}\end{array}$ & 470 & 17.5 \\
\hline $\begin{array}{l}\text { L-Lysine } 0.5 \mathrm{mM} \\
\text { +L-threonine } 0.5 \mathrm{mM}\end{array}$ & 570 & 0 \\
\hline
\end{tabular}

lysine, $42.4 \%$ by L-threonine and $22.8 \%$ by L-methionine, where the concentration of each amino acid required for the maximal inhibition under assay conditions were almost the same and $5 \times 10^{-2} \mathrm{M}$. Furthermore, the concerted inhibitory effect of $L$-threonine and L-lysine on aspartokinase activity was observed in Bacillus polymixa and other bacteria..$^{21 \sim 24}$ Such a concerted effect was pronounced on the action of aspartokinase of the present organism when both of these amino acids were concomitantly supplied at more diluted concentration of $5.0 \mathrm{~mm}$ to the reaction mixture. As shown in Table VII, $5.0 \mathrm{~mm}$ of threonine or lysine showed either none or a little inhibitory effect but the coexistence of these amino acids at each concentration of $5.0 \mathrm{~mm}$ in the reaction mixture gave rise to a remarkable inhibition and the rate attained to $93.8 \%$, although more diluted concentration such as $0.5 \mathrm{~mm}$ of each amino acid brought about no concerted inhibition. In respect of this feature in the concerted inhibition of aspartokinase by lysine and threonine, the present bacterium, $B$. colistinus, well coincides with $B$. polymixa. When $\alpha, \gamma$-diaminobutyric acid as well as $\alpha$-aminobutyric acid were supplied either individually or concomitantly with lysine alone or with lysine and threonine, they should no, if any, effect, as seen from Tables VI and VII, so that the releasing effect of these monoamino and diaminobutyric acids from the inhibition by lysine, either alone or together with threonine, was almost eliminated in this case, contrary to the case of this effect of $\alpha$-aminobutyric acid on Bacillus megaterium L-2 enzyme. ${ }^{251}$ Such an inertness of $\alpha, \gamma-$ diaminobutyric acid, including the fact that

21) H. Paulus and E. Gray, J. Biol. Chem., 239, PC 4008 (1964).

22) P. Datta and H. Gest, Proc. Natl. Acad. Sci. $U . S ., 52,1004$ (1964).

23) K. Nakayama et al., Agr. Biol. Chem., 30, 611 (1966).

24) R. Miyajima et al., J. Biochem. (Japan), 63, 139 (1968).

25) K. Sasaki et al., Amino acid and Nucleic acid, 10,60 (1964). 
there exists no activating enzyme for this diaminobutyric acid in the present bacterium ${ }^{26}$ as mentioned previously, may be noticeable. According to E. R. Stadtman's concept, ${ }^{27}$ aspartokinase of $E$. coli is distinguishable in its isozymes specific for the biosynthesis of lysine or threonine. This may be applicable to the present aspartokinase receiving the concerted inhibition by lysine and threonine, although this synergism may be supposed to be always broken by the mobilization of threonine to the biosynthesis of colistin. Thus, the aspartokinase action may be inclined to the synthesis of $\alpha, \gamma$-diaminobutyric acid especially on the basis of the inertness of this diaminobutyric acid and accordingly this may result in more formation of $\alpha, \gamma$-diaminobutyric acid than that of threonine to be involved abundantly in colistin molecule. Of the amino acids which are abundantly biosynthesized in the colistin-producing cell, valine and isolencine may be mobilized to form colistin fatty acids such as 6-methyloctanoic acid and isooctanoic acid, 9' so that these amino acids, contrary to leucine and threonine, may not be comprized in colistin peptide.

Furthermore, as indicated in Table VIII,

TABLE VIII. EFFECT OF $\alpha, \gamma$-DIAMINOBUTYRIC ACID ON COLISTIN Formation

$\begin{array}{ccc}\alpha, \gamma \text {-Diaminobutyric } & \text { Colistin formed } & \begin{array}{c}\text { Activity ratio } \\ \text { acid }(\mathrm{mg} / \mathrm{ml})\end{array} \\ 0 & 8 \mathrm{u} / \mathrm{ml}) & 100 \\ 1.0 & 1100 & 137 \\ 2.5 & 1100 & 137 \\ 5.0 & 1300 & 162 \\ 10.0 & 1800 & 225\end{array}$

Reaction mixture; cell suspension $2 \mathrm{ml}$ (corresponding to $30 \mathrm{mg}$ dried cell), amino acids mixture $1.0 \mathrm{ml}$, $1 \mathrm{M}$ glucose $0.1 \mathrm{ml}, \mathrm{M} / 10$ phosphate buffer ( $\mathrm{pH} 7.2$ ), $\alpha, \gamma$-diaminobutyric acid, total volume $4.0 \mathrm{ml}$. Incubation; at $30^{\circ} \mathrm{C}$, for $3 \mathrm{hr}$.

26) M. Ito, K. Aida and T. Uemura, Abstracts of papers, the 41 th General Meeting of Japanese Biochemical Society, Tokyo, Japan, September, 1968 p. 535 .

P. 27 ) E. R. Stadmen, Adv. in Enzymology, 28, 65 (1966). the more concentrated $\alpha, \gamma$-diaminobutyric acid was supplied to the culture of heavy inoculum in the medium containing amino acid mixture and glucose, the more colistin was formed during $3 \mathrm{hr}$ incubation. In contrast to the inactivity of the colistin fatty acids such as 6-methyloctanoic acid and isooctanoic acid as mentioned previously, ${ }^{91}$ this may be ascribed, at least partially, to the above inertness of $\alpha, \gamma-$ diaminobutyric acid which in turn seems likely to be rate-limiting factor for the biosynthesis of colistin.

\section{DISCUSSION}

In bacteria, lysine or ornithine is biosynthesized via $\mathrm{N}$-succinylated or $\mathrm{N}$-acetylated intermediates, protecting each $\alpha$-amino group from other attacks. ${ }^{28 \sim 301}$ In contrast, in fungi or yeast such as Neurospora crassa or Torula utilis, these basic amino acids are biosynthesized without such protection process of $\alpha$-amino group as $\mathrm{N}$-acetylation. Thus, bacterial biosyntheses of ornithine and lysine, both of which are diamino- $n$-fatty acid of $\mathrm{C}_{5}$ or $\mathrm{C}_{6}$, are distinguishable from fungal ones by the protection process of $\alpha$-amino group. In turn, $\alpha, \gamma$-diaminobutyric acid, also diamino- $n$-fatty acid of $\mathrm{C}_{4}$, was proved to be biosynthesized without any $\mathrm{N}$-acetylation in the present bacterium, as already mentioned. The biosynthetic type in this case is thus assumed rather to belong to the fungal type. The abnormality of $\alpha, \gamma$-diaminobutyric acid in its biosynthetic type may be based upon either the kind of bacteria or the difference in length of carbon chain of those diamino fatty acids. In any case, it is noticeable to find non-Nacetylated biosynthesis of diamino fatty acid in bacteria.

In the present study, the deaminated pro-

28) H. J. Vogel., Proc. Natl. Acad. Sci. U.S., 39, 578 (1953).

29) C. Gilvarg, Biochem. Biophys. Acta, 24, 216 (1957).

30) C. Gilvarg, J. Biol. Chem., 234, 2955 (1959). 
duct of $\alpha, \gamma$-diaminobutyric acid in the transamination with $\alpha$-ketoglutaric acid was proved to be aspartic $\beta$-semialdehyde by the comparison with the spot of the authentic compound on the paperchromatogram. It is yet doubtful whether the deaminated product is aspartic $\beta$-semialdehyde alone or contaminated with $\alpha$-keto- $\gamma$-aminobutyric acid. Further studies to confirm the deaminated product are now in progress.

Since the formation of this antibiotic was well stimulated by addition of $\alpha, \gamma$-diaminobutyric acid to the culture medium and colistin fatty acids were of no effect as previously mentioned, $\alpha, \gamma$-diaminobutyric acid is considered to be rate-limiting factor in colistin formation. In this connection, glutamic acid which is assumed as a main amino donor to aspartic $\beta$-semialdehyde in the transamination is of importance in the formation of $\alpha, \gamma$-diaminobutyric acid. As the colistin-producing cell of this bacterium is defective in TCA cycle, glutamic acid is considered to be formed via other pathway than TCA cycle like in Gluconobacter suboxydans which also lacks TCA cycle. ${ }^{311}$ This will be further inquired in future.

It is noticeable that the colistin-producing cell is defective in TCA cycle, thus resulting in the inclination to an abundant formation of valine and leucine in amino acid metabolism. In this respect, the formation of peptide antibiotic, colistin, is assumed as a kind of fermentation and in place of cell protein which requires for its synthesis large amount of ATP yielded through TCA cycle, this peptide may be formed due to the defect of TCA cycle in the colistin-producing cell. Since the present organism lacks $\alpha, \gamma$-diaminobutyryl-s-RNA synthetase, ${ }^{26)}$ the colistin formation, of which mechanism, however, is as yet obscure, may be dispensable for rich ATP because of its deviation from the ribosomal peptide biosynthsis.

31) Vernon H. Cheldelin, Metabolic Pathways in Microorganisms, John Wiley \& Sons, Inc. New York (1960). 